\title{
Comparison of High Performance Fly Ash Concrete Using Nano Silica Fume on Different Mixes
}

\author{
S. Suresh Sankaranarayannan'1, J. Revathi Jagadesan² \\ ${ }^{1}$ Department of Civil Engineering, Sona College of Technology, Salem, India \\ ${ }^{2}$ Anna University, Chennai, India \\ Email: er_revas05@yahoo.co.in
}

Received 26 March 2016; accepted 25 April 2016; published 7 June 2016

Copyright (C) 2016 by authors and Scientific Research Publishing Inc.

This work is licensed under the Creative Commons Attribution International License (CC BY). http://creativecommons.org/licenses/by/4.0/

(c) () Open Access

\begin{abstract}
This paper investigates the experimental results on the effect of nano silica fume on compressive strength development of concretes containing high volume fly ash (HVFA). The effect of various silica fumes contents such as $1 \%, 2 \% \& 3 \%$ (wt. \%) as partial replacement of cement on the compressive strength of cements is evaluated in the first part. The nano silica fume content which exhibits the highest compressive strength above is used in high volume fly ash concretes containing $30 \%$ and $50 \%$ class $\mathrm{F}$ fly ash. The results show that among three different silica fumes contents, the addition of $1 \%$ increases the compressive strength of concretes. The addition of $1 \%$ silica fume also increases the early age and 28 days compressive strengths of HVFA concretes.
\end{abstract}

\section{Keywords}

Silica Fume, Fly Ash, Compressive Strength, Concrete

\section{Introduction}

As a recent development, supplementary cementitious materials (SCM's) are being increasingly used in concrete for improvement in its properties and for reducing amount of cement. The commonly used SCMS such as fly ash, Calcium carbon material, metakaolin and slag are widely used because of their significant contribution and availability in improving the concrete properties. To produce environment friendly "green concrete" at low cost and in view of sustainability, the partial replacement of cement by SCMS in concrete is employed. Therefore researchers have investigated the use of high volume fly ash as partial replacement of cement in concrete that has enormous impacts in reducing the cost and enhancing its sustainability. The use of fly ash as partial replacement 
of cement in concrete is limited to around $15 \%$ to $20 \%$ by mass of cement which is not adequate to make concrete more sustainable. Several studies have reported that the use of HVFA in concrete provides higher durable properties than ordinary concretes in low water-cement ratio [1]-[4]. Although high volume fly ash concretes show promising performance compared to concrete, yet its low early age strength development is still a concern for wide structural application [5] [6].

Nanotechnology is gaining widespread attention and being applied in many fields to formulate materials with novel functions due to their unique physical and chemical properties. Nano material is defined as a very small size particle in a scale of $10^{-9}$ meter, produced from modification of atoms and molecules in order to produce larger surface area [7]. The addition of nano particles in concrete is more effective than micro size particles and is recognized as a means to improve the strength and durability properties of concrete. Most of the work to date with nano particles has been done using nano carbon $\left(\mathrm{CaCO}_{3}\right)$, nano iron $\left(\mathrm{Fe}_{2} \mathrm{O}_{3}\right)$, nano titanium oxide $\left(\mathrm{TiO}_{2}\right)$, nano-alumina $\left(\mathrm{Al}_{2} \mathrm{O}_{3}\right)$, and nano clay particles. Nano particles act as nuclei for cement to accelerate the cement hydration and densify the microstructure of the matrix and the interfacial transition zone (ITZ), thereby reduces the permeability of concrete [8]. In recent years, limited studies have been conducted on the additions of nano silica fume as partial replacement of cement in concrete on the hydration and compressive strength behavior.

Using nanotechnology tool, it is easy to modify the nano/basic structure of the materials to improve the materials bulk properties such as mechanical performance, durability, sustainability and volume stability. Recently, researchers have shown enormous interest to investigate the properties of building materials such as mechanical, temperature and strain sensing, durability with nano materials [9]. Self-cleaning façade with the addition of titania nano particles to the mortar [10], self sensing cementitious composites [11] and electromagnetic interference(EMI) shielding [12] by the addition of conductive nano materials viz., carbon nano tubes, carbon nano fibers or carbon black have been explored. The application of nano-sized ingredients such as alumina and silica particles and understanding of the hydration behavior are the upcoming research areas dealing with cement and concrete materials [13]-[20].

The effect of nano silica to reduce the calcium leaching and refinement in pore structure of cement paste has been studied [21]. The addition of nano silica improved the performance of cementitious system by controlling the C-S-H degradation under aggressive condition of calcium leaching process.

Composite modified asphalts with nano calcium carbonate (nano $\mathrm{CaCO}_{3}$ ) and nano montmorrillonite (nano MMT) were prepared by melt blending. The results demonstrate that these materials homogeneously disperse in the base asphalt, which lead to an improvement in terms of toughness, strength and thermal stability [22]. The effects of nano calcium carbonate addition on the early age properties of ultra-high-performance concrete cured at simulated cold and normal field conditions were investigated [23]. These include the development of lowmaintenance structures through eliminating the risk of steel corrosion induced by chloride-based accelerating admixtures, as well as a more environmentally friendly concrete through reducing the cement factor of ultra-highperformance concrete [24]. Concluded that partial replacement of cement with nano phase $\mathrm{Fe}_{2} \mathrm{O}_{3}$ particles improves the split tensile and flexural strength of concrete but decreases its setting time. Here, it is proved that the use of nano-particles up to maximum replacement level of $2 \%$ produce concrete improved tensile strength. Partial replacement of cement with nano phase $\mathrm{Al}_{2} \mathrm{O}_{3}$ particles improves the compressive strength of concrete but decrease its workability [25]-[27]. The increased the $\mathrm{SiO}_{2}$ nanoparticles' content more than 3 wt.\% causes the reduced the split tensile strength because of the decreased crystalline $\mathrm{Ca}(\mathrm{OH})_{2}$ content required for $\mathrm{C}-\mathrm{S}-\mathrm{H}$ gel formation. $\mathrm{SiO}_{2}$ nanoparticles could improve the pore structure of concrete and shift the distributed pores to harmless and few-harm pores. Nano clays are the new generation of processed clays of interest in a wide range of high performance composites Test results show that while nano clay changes rheological properties of bitumen and increases stiffness, it also decreases angle phase and improves ageing resistances, as well.

\section{Experimental Program}

\subsection{Materials}

Ordinary Portland cement Type-I (PC), Class F fly ash (FA) and nano silica fumes are used in all mixes in this study. The nano-silica fume is obtained from Sky spring Nano materials, Inc. of USA with average particle diameter of $15-30 \mathrm{~nm}$. The chemical properties and physical properties of PC, FA and Silica fume are listed in Table 1 and Table 2. 


\subsubsection{Fly Ash}

It is widely accepted that the water required for workability of mortars and concretes depends on the carbon content of fly ash; the more water is needed to produce a paste of normal consistency when carbon content of fly ash is high. Most standards limit the carbon content of fly ash to 5\% while few admit values as high as 7\% [5]. Some researchers [26] have indicated that in HPC fly ash must comply with ASTM C618 or AASHTO M295 that limit loss on ignition to $6 \%$ and $5 \%$. Table $3 \&$ Table 4 show the characteristic and loss on ignition of fly ash.

\subsubsection{Silica Fumes}

Silica fume (SF) is a byproduct of the smelting process in the silicon and ferro-silicon industry. The reduction of high-purity quartz to silicon at temperatures up to $2000 \mathrm{C}$ produce $\mathrm{SiO}_{2}$ vapours, which oxidizes and condense in

Table 1. Chemical composition and physical properties of cementitious materials.

\begin{tabular}{cccc}
\hline Chemical Analysis & Cement (Wt. \%) & Fly Ash (Wt. \%) & Silica Fume \\
\hline $\mathrm{K}_{2} \mathrm{O}$ & - & 0.68 & - \\
$\mathrm{Na}_{2} \mathrm{O}$ & - & 0.31 & - \\
$\mathrm{P}_{2} \mathrm{O}_{5}$ & - & 1.39 & - \\
$\mathrm{TiO}_{2}$ & - & 1.44 & 0.24 \\
$\mathrm{SO}_{3}$ & 2.4 & 0.21 & - \\
$\mathrm{MnO}$ & - & 0.10 & 0.38 \\
$\mathrm{MgO}$ & 2.0 & 1.17 & 0.25 \\
$\mathrm{CaO}$ & 63.9 & 1.61 & 92.70 \\
$\mathrm{SiO}_{2}$ & 20.2 & 51.80 & 2.04 \\
$\mathrm{Al}_{2} \mathrm{O}_{3}$ & 4.9 & 26.40 & 1.08 \\
$\mathrm{Fe}_{2} \mathrm{O}_{3}$ & 2.8 & 13.20 & \\
\hline
\end{tabular}

Table 2. Physical properties.

\begin{tabular}{cccc}
\hline Partial Size & $25 \%-40 \% \leq 7 \mu \mathrm{m}$ & $40 \%$ of $10 \mu \mathrm{m}$ & $15-40 \mathrm{~nm}$ \\
Specific Gravity & 2.7 to 3.2 & 2.6 & - \\
Surface Area(m $/ \mathrm{g})$ & - & - & 40 \\
Loss on ignition (\%) & 2.4 & 0.5 & - \\
\hline
\end{tabular}

Table 3. Characteristics of fly ash.

\begin{tabular}{|c|c|c|c|}
\hline Moisture (\%) & 0.09 & Total: $\mathrm{S}_{\mathrm{i}} \mathrm{O}_{2}+\mathrm{AL}_{2} \mathrm{O}_{3}+\mathrm{Fe}_{2} \mathrm{O}_{3}(\%)$ & 87.73 \\
\hline Loss on ignition (\%) & 7.03 & $\mathrm{Na}_{2} \mathrm{O}(\%)$ & 0.44 \\
\hline Fineness $>45 \mu \mathrm{m}(\%)$ & 27.53 & $\mathrm{~K}_{2} \mathrm{O}(\%)$ & 1.53 \\
\hline Fineness $>75 \mu \mathrm{m}(\%)$ & 14.30 & $\mathrm{MgO}(\%)$ & 1.45 \\
\hline Free $\mathrm{CaO}(\%)$ & 0.00 & $\mathrm{SO}_{3}(\%)$ & 0.25 \\
\hline Total $\mathrm{CaO}(\%)$ & 2.25 & Chloride (\%) & 0.00 \\
\hline $\mathrm{S}_{\mathrm{i}} \mathrm{O}_{2}(\%)$ & 58.46 & $\mathrm{P}_{2} \mathrm{O}_{5}(\%)$ & 0.16 \\
\hline $\mathrm{AL}_{2} \mathrm{O}_{3}(\%)$ & 21.47 & $\mathrm{TiO}_{2}(\%)$ & 0.93 \\
\hline $\mathrm{Fe}_{2} \mathrm{O}_{3}(\%)$ & 7.81 & Specific Gravity & 2.36 \\
\hline
\end{tabular}

Table 4. Loss on ignition of fly ash.

\begin{tabular}{ccc} 
Fly Ash & L.O.I. (\%) \\
\hline Total 'as received' & 7 \\
Particles $>75 \mu \mathrm{m}$ & 26.5 \\
Particles $<75 \mu \mathrm{m}$ (enhanced Fly Ash) & 3.5 \\
\hline
\end{tabular}


the low-temperature zone to tiny particles consisting of non-crystalline silica. Higher the silicon content in the alloy results in the higher silica content in silica fume. The reason is the same furnace can produce different alloys, it is necessary to know the cradle of any silica fume to be used in concrete. In scrupulous, ferrosilicon with a 50-per cent content of silicon results in a silica fume with a content of silica of only about 80 per cent emblematic silica contents are as follows: silicon metal, 94 to 98; 90 percent ferrosilicon, 90 to 96; and 75 per cent ferrosilicon, 86 to 90 .

Silica fume has been recognized as pozzolanic admixture that effective in enhancing the mechanical properties by using silica fume along with super plasticizers, it is defined easier to obtain compressive strengths of order of 100 - $150 \mathrm{MPa}$ in laboratory. Adding silica fume to concrete improves the durability of concrete through reduction in the permeability, refined pore structure, leading to a reduction in the diffusion of harmful ions; reduce calcium hydroxide content which results in a higher resistance to sulphate attack Improvement in durability will also improve the ability of silica fume concrete in protecting the embedded steel from corrosion.

Figure 1 shows the schematic diagram of silica fume production. The silica fume is collected a very large filters in the bag house and then made available for use in concrete

\subsubsection{Properties of Silica Fume}

\section{1) Physical Properties}

Silica fume particles are extremely small, with more than $95 \%$ of the particles finer than $1 \mu \mathrm{m}$. Its typical physical properties are given in Table 5. Silica fume colour is either premium white or grey shown in Figure 2.

\section{2) Chemical Composition}

Silica fume is composed primarily of pure silica in non-crystalline form. X-ray diffraction analysis of different silica fumes reveals that material is essential.

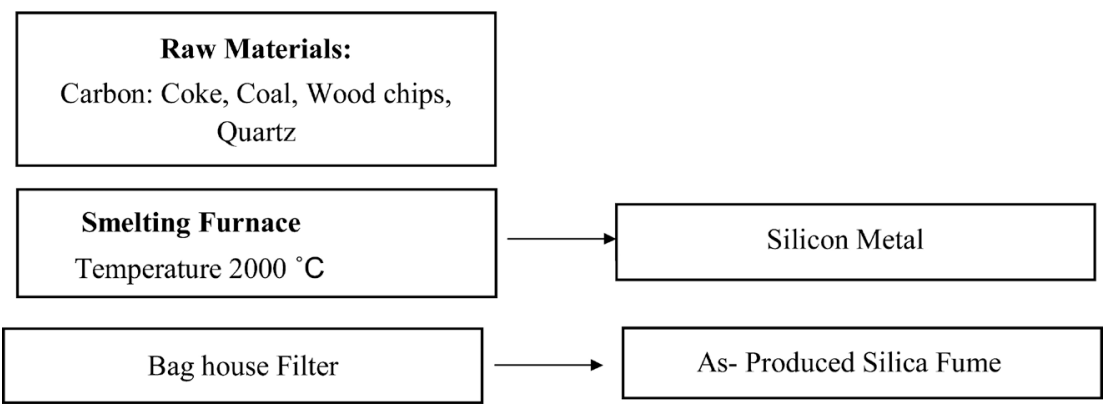

Figure 1. Schematic diagram of silica fume production.

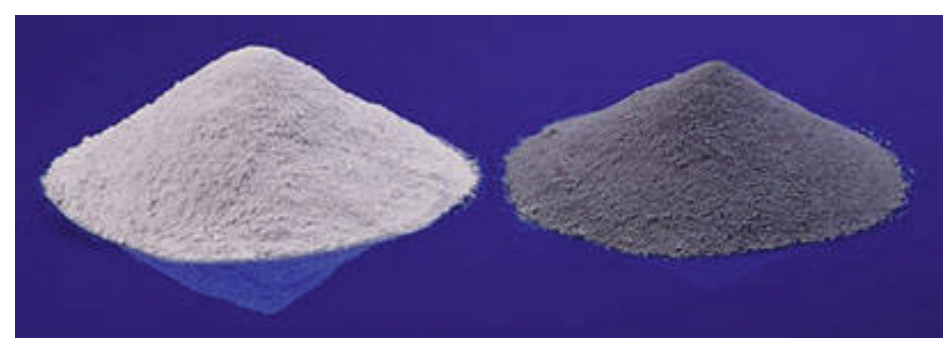

Figure 2. Silica fume.

Table 5. Typical physical properties of silica fume.

\begin{tabular}{cc}
\hline Property & Value \\
\hline Particle size (typical) & $<1 \mu \mathrm{m}$ \\
Bulk density As Produced & $130-430 \mathrm{~kg} / \mathrm{m}^{3}$ \\
Slurry & $1320-1440 \mathrm{~kg} / \mathrm{m}^{3}$ \\
Densified & $480-720 \mathrm{~kg} / \mathrm{m}^{3}$ \\
Specific gravity & 2.2 \\
Surface Area & $13,000-30,000 \mathrm{~m}^{2} / \mathrm{Kg}$ \\
\hline
\end{tabular}




\subsection{Mixture Proportions}

The mixture proportion is shown in Table 6 respectively. The effects of different nano-silica fumes contents on compressive strength development of HVFA cement are evaluated. The first series is the control cement. The effects of high fly ash content $30 \%$ and $50 \%$ as partial replacement of cement on compressive strength of cements are evaluated in second series. The third series investigates the effects of different nano-silica fumes contents (e.g. $1 \%, 2 \%$ and $3 \%$ ) as partial replacement of cement on compressive strength of cements. The nano silica fume content that exhibits the highest compressive strength in the third series is used in the fourth series to study its effect on the compressive strength of cements containing 30\% and 50\% class F fly ash(by wt) as partial replacement of cement.

\subsection{Mixing Methods}

The concrete mixes are prepared in a pan mixer with water/binder ratio of 0.4 and sand/binder ratio of 2.75. Dry mixing time of cement, fly ash, Nano-silica fume and aggregates are extended to 4 - 5 minutes due to higher volume of mix and presence of coarse aggregates. Standard cylinders having diameter of $100 \mathrm{~mm}$ and height of $200 \mathrm{~mm}$ are cast and cured in water at room temperature. The compressive strengths of concretes are determined at 3, 7 and 28 days according to ASTM C873 standard. Figure 3 shows casting of specimens for cube and cylinder. Figure 4 shows compressive strength test.

\section{Results and Discussion}

\subsection{Effect of Silica Fume on Workability of Concretes}

The effect of silica fume on workability of control cement concrete is evaluated using flow table test according to ASTM C1437 (2012). It can be seen from Figure 5 that the concrete containing nano silica fume exhibited

Table 6. Mixture proportions of concretes.

\begin{tabular}{|c|c|c|c|c|c|c|c|}
\hline Series & Mix Designation & $\begin{array}{l}\text { Cement } \\
\left(\mathrm{kg} / \mathrm{m}^{3}\right)\end{array}$ & $\begin{array}{c}\text { Class F Fly ash } \\
\left(\mathrm{kg} / \mathrm{m}^{3}\right)\end{array}$ & $\begin{array}{c}\text { Nano Silica Fume } \\
\left(\mathrm{kg} / \mathrm{m}^{3}\right)\end{array}$ & $\begin{array}{c}\text { Sand } \\
\left(\mathrm{kg} / \mathrm{m}^{3}\right)\end{array}$ & $\begin{array}{c}\text { Coarse Aggregate } \\
\left(\mathrm{kg} / \mathrm{m}^{3}\right)\end{array}$ & $\begin{array}{r}\text { Water } \\
\left(\mathrm{kg} / \mathrm{m}^{3}\right)\end{array}$ \\
\hline 1 & PC & 300 & - & - & 513 & 888 & 123 \\
\hline \multirow{2}{*}{2} & FA 30 & 210 & 90 & - & 513 & 888 & 123 \\
\hline & FA 50 & 150 & 150 & - & 513 & 888 & 123 \\
\hline \multirow{3}{*}{3} & NS1 & 297 & - & 3 & 513 & 888 & 123 \\
\hline & NS2 & 294 & - & 6 & 513 & 888 & 123 \\
\hline & NS3 & 291 & - & 9 & 513 & 888 & 123 \\
\hline \multirow{2}{*}{4} & FA29\%NS1\% & 210 & 87 & 3 & 513 & 888 & 123 \\
\hline & FA49\%NS1\% & 150 & 147 & 3 & 513 & 888 & 123 \\
\hline
\end{tabular}

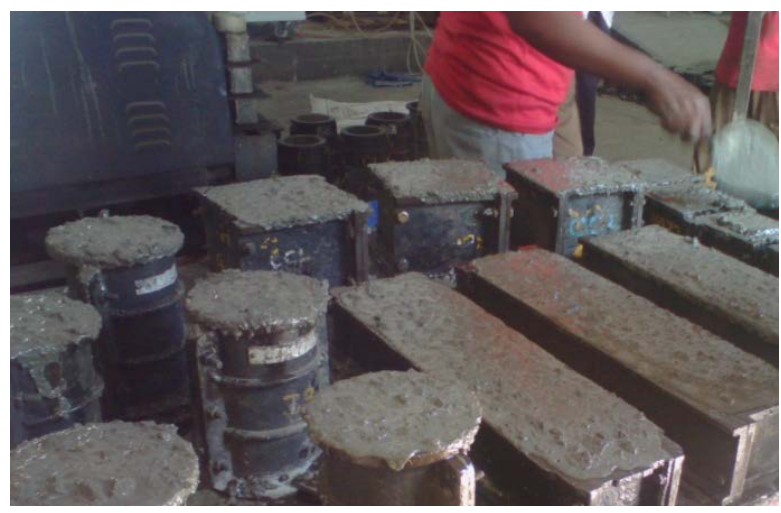

Figure 3. Casting of specimens. 


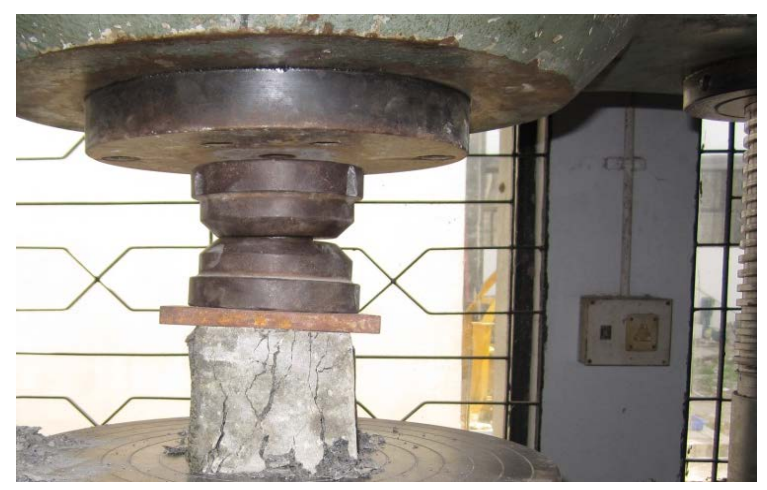

Figure 4. Compressive strength test.

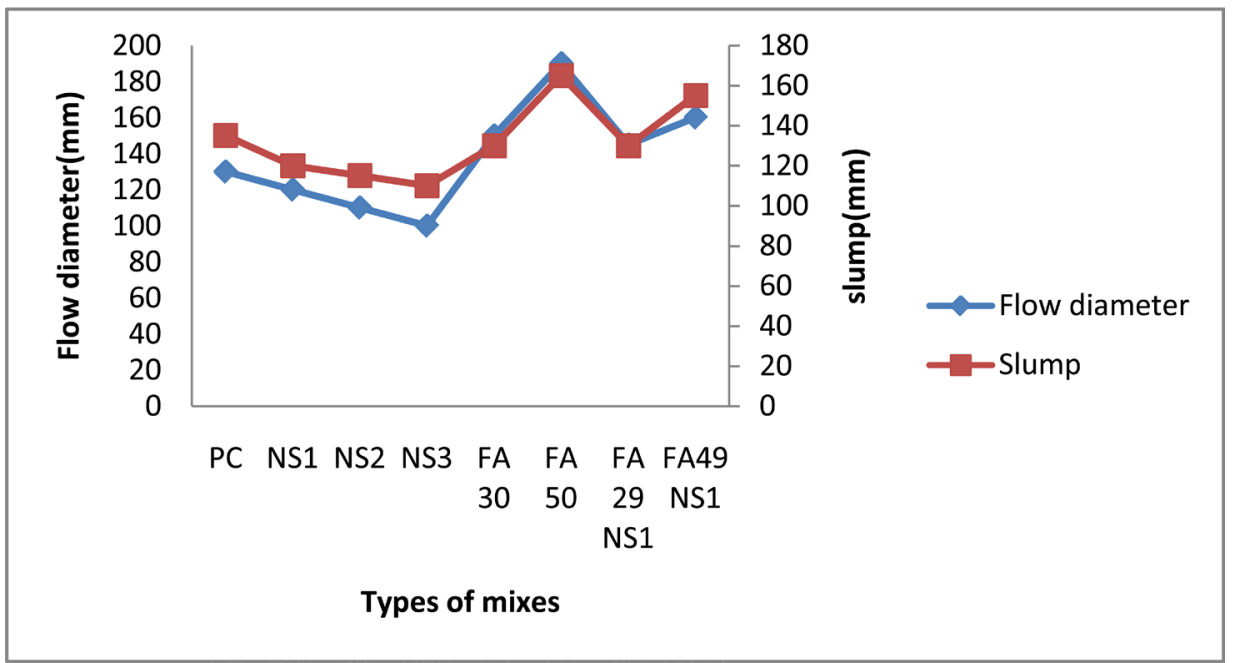

Figure 5. Effect of nano silica fume on workability of concrete.

slightly lower workability than the control cement concrete and the flow values decreases with increase in nano-silica fumes contents as partial replacement of cement. The effect of $1 \%$ (by wt.) silica fumes on workability of HVFA concretes can also be shown in Figure 5.

Similar to control concrete, the use of $1 \%$ silica fume also reduced the workability of HVFA concrete. For instance, the FA30 yielded a flow diameter of $140 \mathrm{~mm}$ while this flow is reduced to 135 when $1 \%$ nano-silica fume is used as partial replacement of fly ash (e.g. FA 29NS1 concrete). Similar behavior is observed in FA49NS1 concrete. This can be explained due to high specific surface area of nano-silica fume. This shows that workability of concrete containing HVFA and combined HVFA with nano-silica fumes are also measured to evaluate the effect of nano-silica fume. The high surface area of nano-silica fume can be attributed to the reduced workability of concrete and their HVFA counterparts.

\subsection{Effect of Nano-Silica Fume on Compressive Strength of Cement}

Figure 6 shows the effect of 1\%, $2 \%$ \& 3\% nano-silica fume on 3, 7 \& 28 days compressive strength of ordinary concrete.

It can be seen in Figure 7(a) that the concretes containing 1\%, 2\% \& 3\% Nano-silica fumes exhibited higher compressive strength at all ages than the ordinary concrete and among the three Nano-silica fume contents the $1 \%$ Nano-silica fume exhibited the highest compressive strength at all ages. Therefore $1 \%$ Nano-silica fume is used in HVFA concretes to evaluate its synergistic effect with fly ash on the compressive strength development. It can be seen in Figure 7(b), that the 1\% Nano-silica fume significantly improved the $3 \& 7$ days compressive strength of HVFA concrete containing $29 \%$ fly ash, where about $47 \%$ and $44 \%$ improvement is observed respectively. At 28, the improvement is even higher (about $87 \%$ ) for the concrete containing $29 \%$ fly ash. 


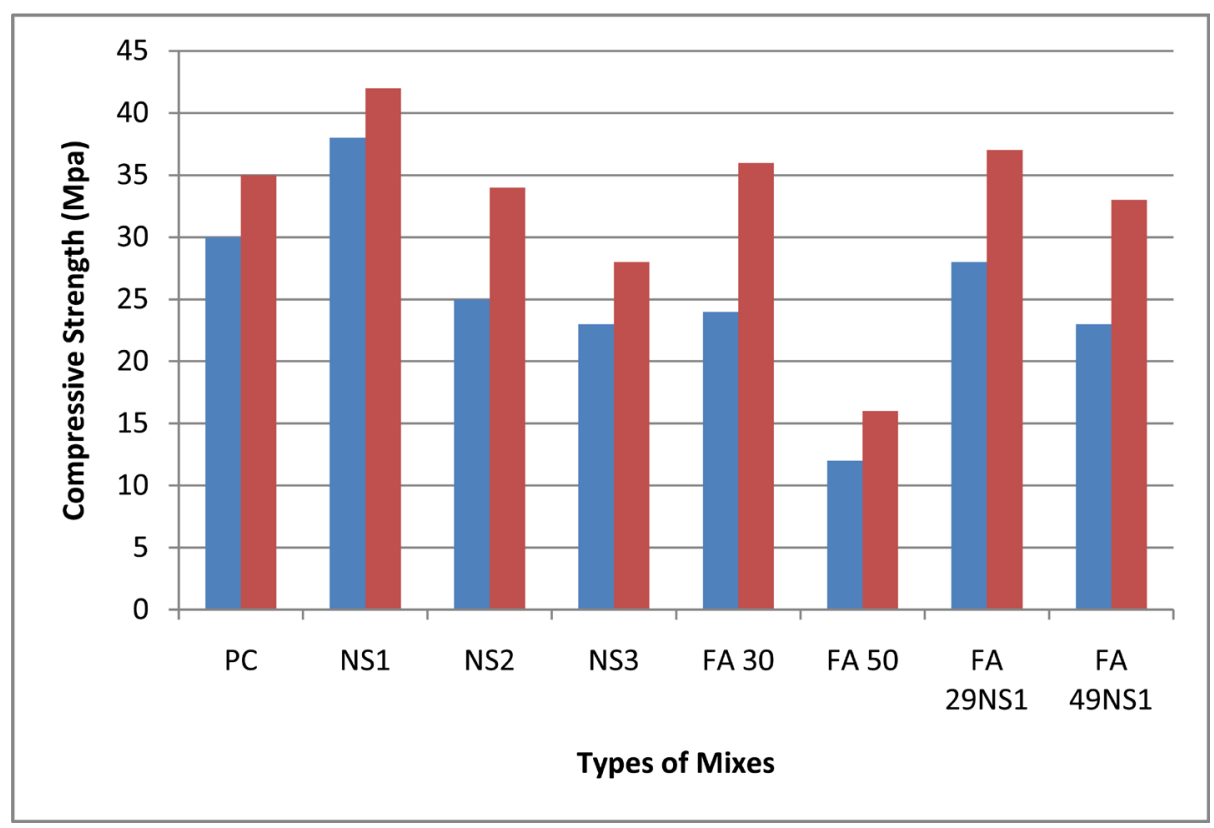

Figure 6. Effect of nano-silica fume on compressive strength of concrete \& high volume fly ash concrete (7 days, 28 days).

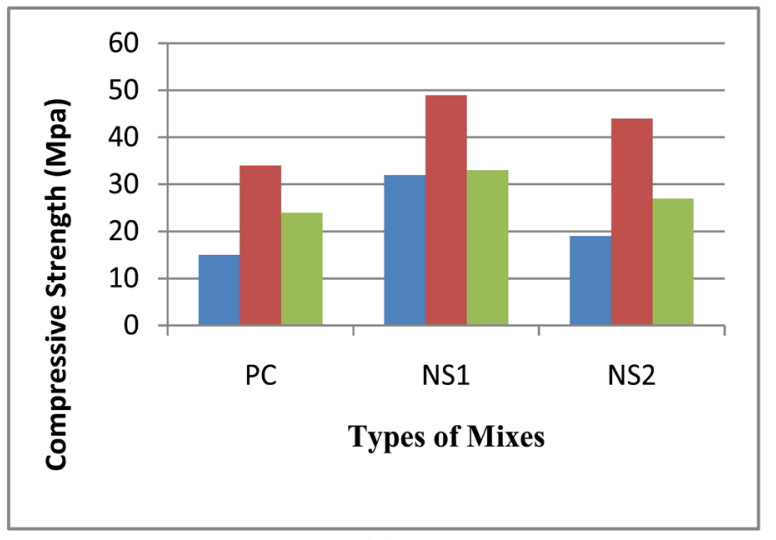

(a)

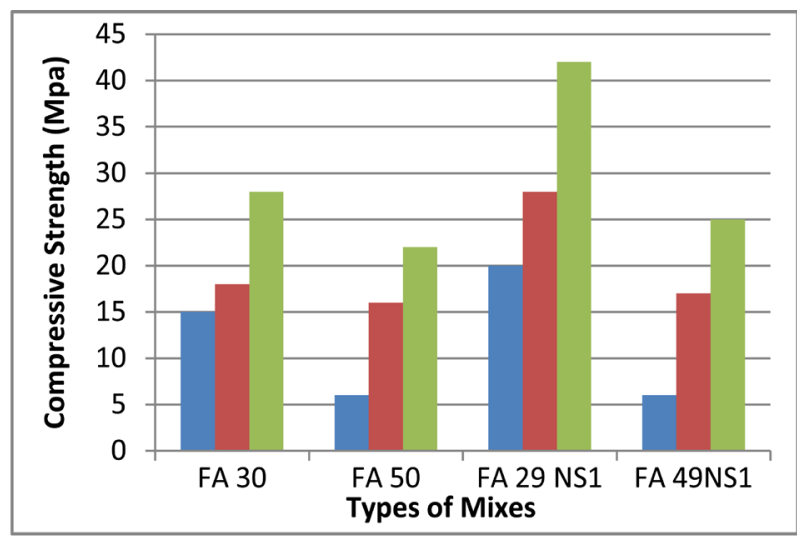

(b)

Figure 7. (a) Concretes containing nano-silica fume (3 days, 7 days, 28 days); (b) HVFA concrete containing silica fume (3 days, 7 days, 28 days).

\section{Conclusions}

Based on workability 3, 7 \& 28 days compressive strength results on the effect of nano-silica fume in high volume fly ash concrete, the following conclusions can be drawn.

1) Nano-silica fume slightly reduced the workability of both ordinary \& HVFA concretes.

2) Concrete containing 1\% Nano-silica fume as partial replacement of cement exhibited about $140 \%$ improvement of early age compressive strength (e.g. at 3 \& 7 days) as compared to control concrete. At 28 days, the improvement was $62 \%$.

3) The addition of 1\% Nano-silica fume increased the compressive strength at early ages (e.g. 3 \& 7 days) of HVFA concrete containing [28].

4) $1 \%$ fly ash by about $44 \%$ - 46\%. At 28 days, the improvement was about $53 \%$.

5) The compressive strengths of FA29 NS1 concrete at all ages exceeded the ordinary Portland cement concrete.

6) This shows that sustainable concrete with $40 \%$ less cement can be produced by adding $1 \%$ nano-silica fume. 


\section{References}

[1] Chalee, W., Jaturapitakkul, C and Chindaprasirt, P. (2009) Predicting the Chloride Penetration of Fly Ash Concrete in Seawater. Marine structures, 22, 341-353. http://dx.doi.org/10.1016/j.marstruc.2008.12.001

[2] Crouch, L.K., Hewitt, R. and Byard, B. (2007) High Volume Fly Ash Concrete. 2007 World of Coal Ash (WOCA), Northern Kentucky, 7-10 May 2007, 1-14.

[3] Dhir, R.K. and Jones, M.R. (1999) Development of Chloride-Resisting Concrete Using Fly Ash. Fuel, 78, $137-142$. http://dx.doi.org/10.1016/s0016-2361(98)00149-5

[4] Tahir, M.A. and Sabir, M. (2005) A Study on Durability of Fly Ash Cement Mortar. 30th Conference of Our World in Concrete and Structures, Singapore, 23-24 August 2005, 1-7.

[5] Xu, G.Q., Liu, J.H., Qiao, L. and Sun, Y.M. (2010) Experimental Study on Carbonation and Steel Corrosion of High Volume Fly Ash Concrete. Asia-Pacific Power and Energy Engineering Conference, Chengdu, 28-31 March 2010, 1-4.

[6] Murali, G., Vasanth, R., Balasubramaniam, A.M. and Karikalan, E. (2012) Experimental Study on Compressive Strength of High Volume Fly Ash Concrete. International Journal of Engineering and Development, 4, 317-320.

[7] Mann, S. (2006) Nanotechnology and Construction, Nano Forum Report on Nanotechnology and Construction. 1-55. www.nanoforum.org

[8] Sanchez, F. and Sobolev, K. (2010) Nano Technology in Concrete-A Review. Construction and Building Materials, 24, 2060-2071. http://dx.doi.org/10.1016/j.conbuildmat.2010.03.014

[9] Bjornstrom, J., Martinelli, A., Matic, A., Borjesson, L. and Panas, I. (2004) Accelerating Effects of Colloidal NanoSilica for Beneficial Calcium-Silicate-Hydrate System. Chemical Physics Letter, 392, 242-248. http://dx.doi.org/10.1016/j.cplett.2004.05.071

[10] Perumal, K. and Sundararajan, R. (2004) Effect of Partial Replacement of Cement with Silica Fume on the Strength and Durability Characteristics of High Performance Concrete. 29th Conference on OUR WORLD IN CONCRETE \& STRUCTURES, Singapore, 25-26 August 2004, 397-404.

[11] Jahromi, S.G. and Khodaii, A. (2009) Effects of Nanoclay on Rheological Properties of Bitumen Binder. Elsevier, Construction and Building Materials, 23, 2894-2904.

[12] Pera, J., Husson, S. and Guilhot, B. (1999) Influence of Finely Ground Limestone on Cement Hydration. Cement and Concrete Composites, 21, 99-105. http://dx.doi.org/10.1016/S0958-9465(98)00020-1

[13] Camiletti, J., Soliman, A.M. and Nehdi, M.L. (2013) Effect of Nano-Calcium Carbonate on Early Age Properties of Ultra High Performance Concrete. Magazines of Concrete Research, 65, 297-307.

[14] Jo, B.W., Kim, C.H. and Lim, J.H. (2007) Investigations on the Development Powder Concrete with Nano-SiO Particles. Journal of Civil Engineering, 11, 37-42.

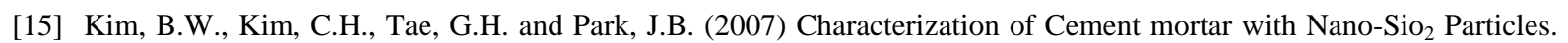
Construction and Building Materials, 21, 1351-1355. http://dx.doi.org/10.1016/j.conbuildmat.2005.12.020

[16] Li, G. (2004) Properties of High Volume Fly Ash Concrete Incorporating Nano-Silica. Cement and Concrete Research, 34, 1043-1049. http://dx.doi.org/10.1016/j.cemconres.2003.11.013

[17] Nazari, A., Riahi, S., Riahi, S., Shamekhi, S.F. and Khademno, A. (2010) Mechanical Properties of Cement Mortar with Al O Nano Particles. Journal of American Science, 6, 94- 97.

[18] Sorelli, L., Constantinides, G., Ulm, F.J. and Toutlemonde, F. (2008) The Nano-Mechanical Signature of Ultra High Performance Concrete by Statistical Nano Indentation Techniques. Cement and Concrete Research, 38, 1447-1456. http://dx.doi.org/10.1016/j.cemconres.2008.09.002

[19] Temiz, H. and Karakeci, A.Y. (2002) An Investigation on Microstructure of Cement Paste 5 Containing Fly Ash and Silica Fume. Cement and Concrete Research, 32, 1131-1132. http://dx.doi.org/10.1016/S0008-8846(02)00749-4

[20] Collepardi, M., Ogoumah, J. J., Skarp, U. and Trol, R. (2002) Influence of Amorphous Colloidal Silica on the Properties of Self Compacting Concretes Proceeding of the International Conference. Challenges in Concrete ConstructionInnovations and Developments in Concrete Materials Construction, Dundee, 9-11 September, 473-483.

[21] Han, N.F., Zhao D.J. and Tang, X.D. (2011) Effect of Nano Calcium Carbonate and Montmorillonite on Properties of Styrene-Butadiene-Styrene Copolymer Modified Asphalt. Applied Mechanics and Materials, 99-100, 1035. http://dx.doi.org/10.4028/www.scientific.net/AMM.99-100.1035

[22] Nazari, A., Riahi, S., Riahi, S., Shamekhi, S.F. and Khademno, A. (2010) The Effects of Incorporation $\mathrm{Fe}_{2} \mathrm{O}_{3} \mathrm{Nano}$ Particles on Tensile and Flexural Strength of Concrete. Journal of American Science, 6, 131-138.

[23] Nazari, A., Riahi, S., Riahi, S., Shamekhi, S.F. and Khademno, A. (2010) Influence of $\mathrm{Al}_{2} \mathrm{O}_{3}$ Nanoparticles on the Compressive Strength and Workability of Blended Concrete. Journal of American Science, 6, 6-9. 
[24] Nazari, A. and Riahi, S. (2011) Splitting Tensile Strength of Concrete Using Ground Granulated Blast Furnace Slag and $\mathrm{SiO}_{2}$ Nano Particles as Binder. Elsevier, "Energy and Building”, 43, 864-872.

[25] ASTM (2010) Standard Test Method for Compressive Strength of Concrete Cylinders Cast in Place in Cylindrical Moulds, ASTM C873/C873M-10a, Annual Book of American Society for Testing Materials Standards, Vol. C 04.02.

[26] Bendapudi, S.C.K. (2011) Contribution of Fly Ash to the Properties of Mortar and Concrete. International Journal of earth Sciences and Engineering, 4, 1017-1023.

[27] Nima, F., Ali, A.A.A. and Demirboga, R. (2011) Development of Nano Technology in High Performance Concrete. Advanced Material Research, 364, 115. http://dx.doi.org/10.4028/www.scientific.net/AMR.364.115

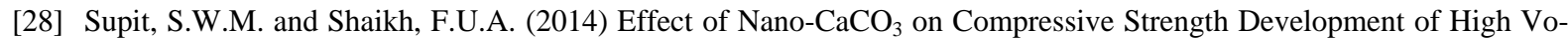
lume Fly Ash Mortars and Concretes. Journal of Advanced Concrete Technology, 12, 178-186. 